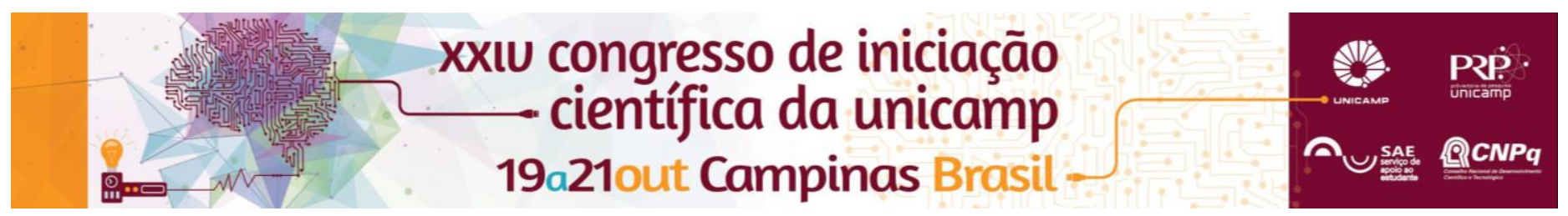

\title{
Influência da complexidade do habitat sobre à estrutura de comunidades de insetos aquáticos em bromélias-tanque.
}

\author{
Cínthia Galeriani*, Cristiele Silva*, João Verçosa*, Salatiel Neto*, Thalia Andreuccetti*, Verônica Sales*, Vinícius \\ Pereira*, Gustavo Migliorini.
}

\section{Resumo}

Habitats mais complexos promovem mais micro-habitats, permitindo aos organismos associados explorar os recursos por diferentes maneiras, aumentando a abundância e diversidade de espécies. Em bromélias-tanque, a complexidade do habitat pode ser avaliada por características como número de folhas da bromélia (n de tanques), volume de água e biomassa de detritos acumulados nos tanques. Neste trabalho investigamos como a complexidade do habitat (avaliada pelas variáveis citadas acima) influencia a abundância de grupos funcionais de insetos aquáticos em bromélias-tanques. Nossos resultados mostram que a estrutura do habitat é um fator determinante para as comunidades associadas aos tanques de bromélias e, além disso, realçam a importância em compreender como a complexidade dos ambientes pode influenciar a estrutura de grupos funcionais nesses ecossistemas.

\author{
Palavras-chave \\ Complexidade, habitat, bromélias, Vriesea sp
}

\section{Introdução}

Habitats mais complexos favorecem mais micro-habitats e nichos para as espécies, aumentando a abundância e diversidade. A estrutura de habitat de Bromélias - tanque pode ser avaliada por variáveis como número de folhas da bromélia ( $n^{\circ}$ de tanques), volume de água e biomassa de detritos nos tanques. No presente projeto, avaliamos como a complexidade do habitat influencia a estrutura de comunidades de insetos aquáticos em ecossistemas bromelícolas. Especificamente, buscamos responder a seguinte pergunta: Bromélias com maior complexidade estrutural apresentam maior abundância de insetos aquáticos?

\section{Resultados e Discussão}

Alguns parâmetros ambientais bromélicos influenciam abundância de certos grupos funcionais analisados Especificamente, a abundância de fragmentadores é maior conforme aumenta a biomassa de detritos nos tanques e quanto maior o número de folhas das bromélias. Para raspadores, existe uma correlação positiva com o volume das bromélias (Fig.1C).Os coletores, filtradores e predadores não apresentaram relação com as variáveis consideradas $(P>0.05) .0$ modelo de RDA foi significativo ( $F 3,18=2.13, P=0.02, R 2$ ajustado=0.14)com a variação na abundância dos grupos funcionais sendo explicada pelo eixo1 da $\operatorname{RDA}(\mathrm{F} 1,18=3.018, \mathrm{P}=0.02$,Fig.1D).

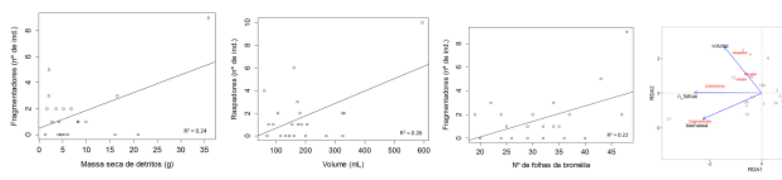

Figura1.(A)Relação entre a abundância de insetos fragmentadores e a massa seca de detritos $(r=0.52, P=0.011)$. (B)Relação entre a abundância de insetos fragmentadores e o número de folhas das bromélias $(r=0.51, P=0.015)$.(C) Relação entre a abundância de insetos raspadores e o volume de água nos tanques das bromélias $(r=0.54, P=0.008)$. (D)Análise de Redundância entre os grupos funcionais e as variáveis ambientais.A proximidade dos grupos funcionais com as setas representa atendência de correlação linear entre eles.Os eixos 1 e 2 da RDA explicam $26 \%$ da variação nos dados.

\section{Conclusões}

Alguns grupos são mais sensíveis que outros para as variáveis consideradas. A variável biomassa de detritos, é a principal fonte de recursos para os detritívoros e fragmentadores. $\mathrm{O} \mathrm{n}^{\circ}$ de folhas das bromélias se relaciona ao $\mathrm{n}^{\circ}$ de tanques. Ainda, o volume está relacionado ao tamanho do habitat Essas três variáveis parecem desempenhar um importante papel na estruturação das comunidades bromelícolas.

\section{Agradecimentos}

Agradecemos a UNICAMP e a disciplina de Ecologia (BE180) por mostrar a base do pensamento ecológico e científico,aos professors e monitores e,em especial,aoGustavoMigliorini,por nos orientar.A Tiago Bernabé pela ajuda no campo. 